\title{
Realizacja zadania „Optymalizacja stosowania składników krwi i produktów krwiopochodnych" w ramach programu polityki zdrowotnej pn. „Zapewnienie samowystarczalności Rzeczypospolitej Polskiej w krew i jej składniki na lata 2015-2020"
}

\author{
Działania Instytutu Hematologii i Transfuzjologii w 2018 roku
}

Implementation of the task "Optimization of the use of blood components and blood products" as part of the health policy program "Ensuring the self-sufficiency of the Republic of Poland in blood and blood components for the years 2015-2020"

Activities of the Institute of Hematology and Transfusion Medicine in 2018

Jolanta Antoniewicz-Papis@, Agata Mikołowska®, Krzysztof Sutkowski, Paweł Kłobukowskiఠ, Krystyna Dudziak, Magdalena Łętowska๑

Zakład Transfuzjologii Instytutu Hematologii i Transfuzjologii w Warszawie

\section{Wstęp}

W nawiązaniu do materiału opublikowanego w ,Journal of Transfusion Medicine” (2018, tom 11, $\mathrm{nr}$ 1:33-37) dotyczącego realizacji programu polityki zdrowotnej pn. „Zapewnienie samowystarczalności Rzeczypospolitej Polskiej w krew i jej składniki na lata 2015-2020” w zakresie zadania „Optymalizacja stosowania składników krwi i produktów krwiopochodnych" Zakład Transfuzjologii Instytutu Hematologii i Transfuzjologii przedstawia sprawozdanie $z$ realizacji tego programu w 2018 roku.

Jak wspomniano w wyżej wymienionej publikacji, jest to program polityki zdrowotnej finansowany przez ministra zdrowia, którego celem ogólnym jest zapewnienie samowystarczalności Rzeczypospolitej Polskiej w krew i jej składniki oraz poprawa bezpieczeństwa krwi i jej składników. W ramach Umowy $z$ dnia 18 sierpnia 2017 roku, zawartej pomiędzy Instytutem
Hematologii i Transfuzjologii a Skarbem Państwa - Ministrem Zdrowia (Umowa nr NCK-F/UM/ /PPZ/69/2017), w 2018 roku Instytut był zobowiązany do realizacji następujących celów szczególowych:

- przeprowadzenie stacjonarnych szkoleń osób zaangażowanych w nadzór nad krwiolecznictwem w podmiotach leczniczych oraz członków Komitetów Transfuzjologicznych;

- opracowanie i prowadzenie platformy e-learningowej.

\section{Realizacja postanowień Umowy w 2018 roku}

Zgodnie $z$ harmonogramem przewidywanym w Umowie, w okresie od 1 stycznia do 22 grudnia 2018 roku pracownicy Zakładu Transfuzjologii Instytutu Hematologii i Transfuzjologii prowadzili równolegle działania w następujących kierunkach: 
- zorganizowano, a następnie przeprowadzono szkolenia dla trzech grup zawodowych wchodzących w skład komitetów transfuzjologicznych: lekarzy, pielęgniarek/położnych, diagnostów laboratoryjnych, lekarzy odpowiedzialnych za gospodarkę krwią i innego personelu bezpośrednio zaangażowanego w działania związane $z$ krwiolecznictwem i nadzór nad przetaczaniem krwi i jej składników;

- przeprowadzono wszelkie niezbędne prace w zakresie opracowania i prowadzenia ogólnodostępnej platformy e-learningowej dla pracowników podmiotów leczniczych — członków Komitetów Transfuzjologicznych oraz osób zaangażowanych w nadzór nad krwiolecznictwem w podmiotach leczniczych.

\section{Szkolenia}

\section{Przygotowania}

W dniu 11 czerwca 2018 roku w wyniku postępowania o udzielenia zamówienia publicznego prowadzonego na podstawie przepisów art. 1380 ustawy z dnia 29 stycznia 2009 r. Prawo zamówień publicznych (t.j. Dz. U. z 2017 r. poz. 1579 z późn. zmianami) dotyczących zamówień publicznych na Usługi społeczne i inne szczególne usługi, Instytut Hematologii i Transfuzjologii podpisał $z$ firmą Global Congress Sp. $z$ o.o. trzyletnią umowę dotyczącą szkoleń. Przedmiotem tej umowy było zorganizowanie i przeprowadzenie $\mathbf{w}$ okresie od września 2018 roku do 30 listopada 2020 roku sześciu (6) dwudniowych szkoleń stacjonarnych w każdym roku, w sumie 18 dwudniowych szkoleń, dla każdej $z$ grup zawodowych wchodzących w skład komitetów transfuzjologicznych: lekarzy, pielęgniarek/położnych, diagnostów laboratoryjnych, lekarzy odpowiedzialnych za gospodarkę krwią i innego personelu bezpośrednio zaangażowanego $\mathrm{w}$ działania związane $z$ krwiolecznictwem oraz nadzór nad przetaczaniem krwi i jej składników. Rekrutację uczestników szkoleń firma przeprowadziła na podstawie informacji i danych przekazanych przez Instytut.

Dla wszystkich uczestników szkoleń przygotowano:

- materiały edukacyjne opracowane na podstawie wkładu merytorycznego przekazanego przez Instytut (skrócony pokaz slajdów, wykorzystywanych przez wykładowców w trakcie trwania szkoleń);

- pomocnicze materiały szkoleniowe;

- certyfikaty szkolenia dla uczestników opracowane na podstawie wzoru przekazanego przez Instytut;
- ankiety oceny dla uczestników, którzy ukończyli szkolenie przygotowane przy współpracy Instytutu i firmy.

W 2018 roku (w odróżnieniu od 2017 r.) Instytut Hematologii i Transfuzjologii, jako realizator programu, był zobowiązany do zamieszczania we wszystkich materiałach szkoleniowych, prezentacjach i certyfikatach, obok własnego logo, również logo Ministerstwa Zdrowia i logo Narodowego Centrum Krwi. W 2017 roku, z uwagi na krótki czas realizacji zadania, na wszystkich materiałach edukacyjnych i szkoleniowych zamieszczono tylko logo Instytutu Hematologii i Transfuzjologii.

Zgodnie $z$ zapisami Umowy, podobnie jak w roku poprzednim, w 2018 roku w celu zapewnienia odpowiedniego poziomu i zasobów przekazywanej wiedzy szkolenia mogły być prowadzone wyłącznie przez wykładowców wskazanych przez Instytut. W szkoleniach w 2018 roku brało udzial 8 wykładowców $z$ Instytutu i 1 osoba spoza Instytutu (w sumie 9 wykładowców). Ogólny plan tematyczny szkoleń (dostosowany do potrzeb poszczególnych grup zawodowych: lekarzy, pielęgniarek, diagnostów laboratoryjnych) obejmował podobne zagadnienia, jak w 2017 roku, tj.:

- służba krwi w Polsce, ze szczególnym uwzględnieniem aktów prawnych, organizacji leczenia krwią w podmiotach leczniczych;

- składniki krwi, produkty krwiopochodne, bezpieczeństwo;

- wskazania do stosowania składników krwi, produktów krwiopochodnych; zasady zarządzania krwią pacjenta (PBM; patient blood management); autotransfuzja;

- udział pielęgniarki w procesie przetaczania;

- zadania pracowni immunologii transfuzjologicznej oraz banku krwi;

- zabiegi lecznicze;

- aspekty bezpiecznego przetaczania krwi;

- zdarzenia, reakcje niepożądane, przypadki kliniczne;

— immunologia transfuzjologiczna, jej znaczenie w bezpiecznym przetaczaniu składników krwi;

- współpraca oddziału szpitalnego z pracownią immunologii i bankiem;

- elementy zarządzania ryzykiem, czuwanie nad bezpieczeństwem krwi;

- prawidłowe zabezpieczenie w składniki krwi;

- znaczenie informatyzacji w krwiolecznictwie;

- zadania komitetu transfuzjologicznego, lekarza odpowiedzialnego za gospodarkę krwią, pielęgniarki i położnej oraz diagnosty laboratoryjnego $\mathrm{w}$ procesie przetaczania. 


\section{Realizacja szkoleń}

Wszystkie szkolenia odbywały się w Best Western Hotel FELIX, ul. Omulewska 24, 04-128 Warszawa zgodnie $z$ następującym harmonogramem:

Kurs I:

- 17-19.09.2018 r. — szkolenie dla diagnostów

- 1-3.10.2018 r. - szkolenie dla pielęgniarek

- 10-12.10.2018 r. — szkolenie dla lekarzy

\section{Kurs II}

- 23-25.10.2018 r. — szkolenie dla diagnostów

- 12-14.11.2018 r. — szkolenie dla pielęgniarek

- 19.21.11.2018 r. — szkolenie dla lekarzy

Podobnie jak w roku poprzednim, w każdej grupie zawodowej zajęcia prowadzono w ciągu 2 dni. W pierwszym dniu szkoleń uczestnicy każdej grupy zawodowej wysłuchali 8 godzin wykładów. W każdym drugim dniu szkoleń, poza wysłuchaniem 7 godzin wykładów, uczestnicy wypełniali anonimowo ankietę, przystępowali do testu zaliczeniowego i oglądali film „The Strange Case of Penny Allison"*. Testy zaliczeniowe oraz klucze do testów sprawdzających wiedzę $z$ poszczególnych wykładów przygotowywali wykładowcy tematów.

Podczas każdego szkolenia przedstawiciele Instytutu uczestniczyli w zajęciach w charakterze obserwatorów i osób wspierających.

W sumie w 2018 roku w obydwu kursach stacjonarnych uczestniczyło w szkoleniach 251 osób z terenu całej Polski: $\mathbf{8 0}$ lekarzy, $\mathbf{8 6}$ pielęgniarek/ /położnych i 85 diagnostów laboratoryjnych. Wszyscy uczestnicy ukończyli kurs szkoleniowy i za udział w szkoleniu otrzymali Certyfikaty i punkty edukacyjne (ryc. 1).

$\mathrm{Na}$ podstawie wyników wypełnianych anonimowo ankiet stwierdzono, że zarówno tematyka szkoleń, jak i ich organizacja zostały przez uczestników wysoko ocenione. W 5-stopniowej skali za wartość merytoryczną wykładów przyznano średnio ponad 4,70 punktów oraz ponad $\mathbf{4 , 6 2}$ punktów za organizację szkoleń. $Z$ ankiet wynikało również, $\dot{z}$ e szkolenia stacjonarne cieszyły się dużym zainteresowaniem.

Wyniki analizy zarówno testów, jak i anonimowych ankiet wraz $z$ ich zbiorczym podsumowaniem stanowiły pomoc przy weryfikacji materiałów szkoleniowych do prezentowania podczas kursów stacjonarnych w latach kolejnych oraz przeznaczonych do zamieszczania na platformie e-learningowej.

\section{Dalsze plany dotyczące szkoleń}

Szkolenia stacjonarne według powyższych założeń będą prowadzone przez Instytut również w kolejnych latach (tj. 2019 i 2020). W sumie w czasie trwania programu planowane jest przeszkolenie łącznie około 800 uczestników z trzech grup zawodowych.

\section{Opracowanie i prowadzenie ogólnodostępnej platformy e-learningowej}

Zgodnie z zapisami Aneksu nr 2 z dnia 5 marca 2018 r. do Umowy nr NCK F/UM/PPZ/69/2017 $\mathrm{z}$ dnia 18 sierpnia $2017 \mathrm{r}$. Instytut Hematologii i Transfuzjologii był zobowiązany w 2018 roku do przeprowadzenia wszelkich niezbędnych prac w zakresie opracowania i prowadzenia ogólnodostępnej platformy e-learningowej dla pracowników podmiotów leczniczych, członków Komitetów Transfuzjologicznych oraz osób zaangażowanych w nadzór nad krwiolecznictwem w podmiotach leczniczych, $\mathrm{w}$ celu przeprowadzenia, w procesie kształcenia na odległość, szkoleń z zakresu krwiolecznictwa. W założeniu zakres tematyczny poszczególnych kursów wykorzystanych w ramach platformy miał być zgodny $z$ zakresem tematycznym szkoleń stacjonarnych prowadzonych w latach 2017 i 2018.

\section{Działania Instytutu związane \\ z przygotowaniem ogólnodostępnej platformy e-learningowej (okres od 1 stycznia do 30 września 2018 r.)}

W ramach działań w zakresie realizacji powyższego zadania w Instytucie dokonano rozpoznania rynku usług na tworzenie platformy e-learning oraz przygotowano i przeprowadzono dwudniowy Dialog techniczny, który miał ułatwić przygotowanie opisu przedmiotu zamówienia (OPZ) oraz wniosku o udzielenie zamówienia publicznego na wykonanie i prowadzenie ogólnodostępnej platformy e-learningowej. W Dialogu technicznym uczestniczyli pracownicy Zakładu Transfuzjologii Instytutu oraz przedstawiciele 4 firm, które odpowiedziały na ogłoszenie. Podczas spotkań, które odbyły się w siedzibie Instytutu na Ursynowie w dniach 19 i 20 marca 2018 roku, przedstawiono przedstawicielom 4 firm jednolity zestaw pytań i zagadnień przygotowany przez pracowników 

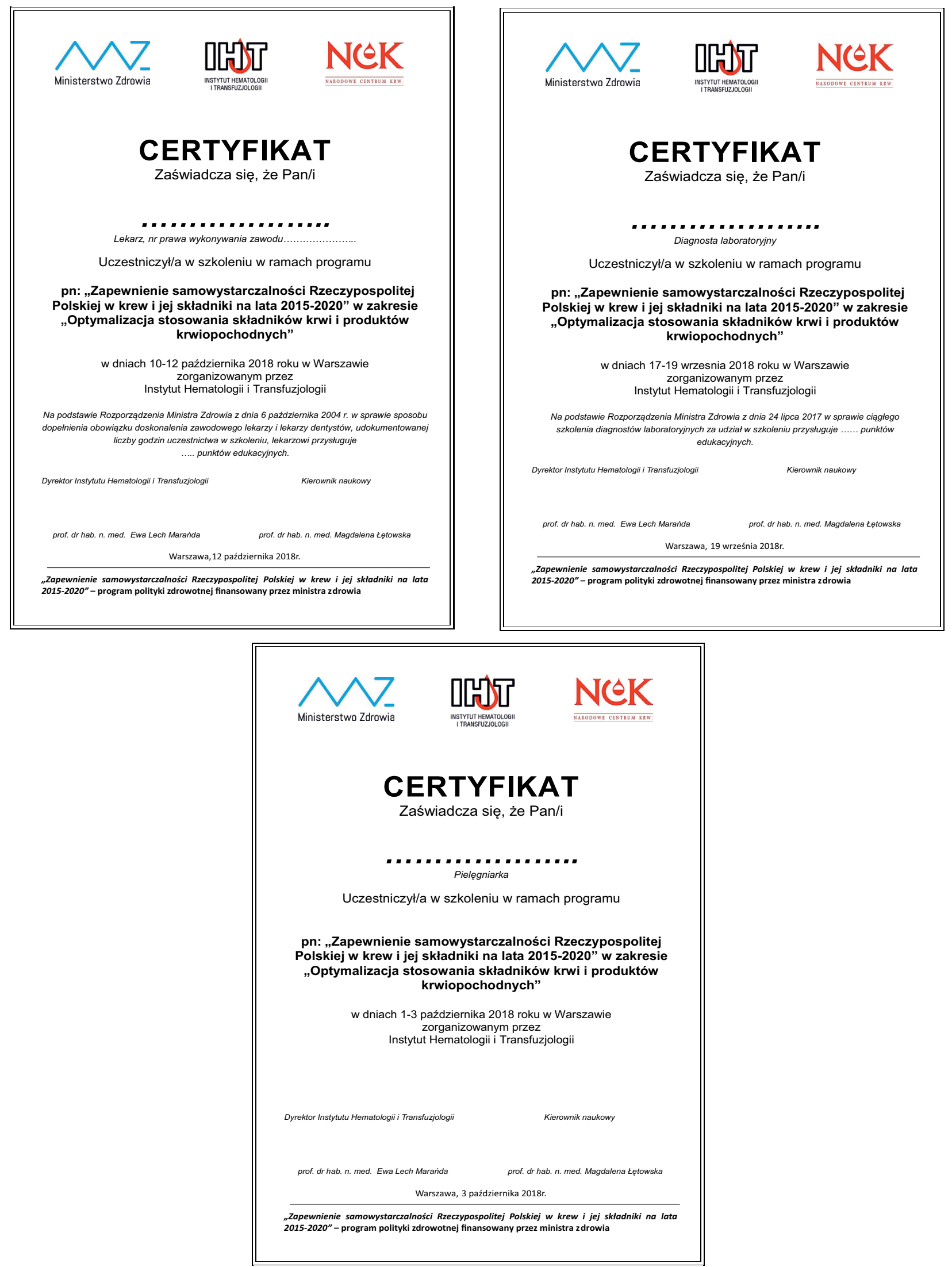

Rycina 1. Certyfikaty potwierdzające udział w szkoleniu stacjonarnym zorganizowanym przez Instytut Hematologii i transfuzjologii w 2018 roku

Figure 1. Certificates confirming participation in the stationary training course organized by the Institute of Hematology and Transfusion Medicine in 2018 
Zakładu Transfuzjologii. Na podstawie odpowiedzi i wyjaśnień udzielonych przez przedstawicieli tych firm przygotowano zapytanie ofertowe w celu ustalenia wartości szacunkowej zamówienia/usługi. W odpowiedzi uzyskano oferty cenowe o znacznej rozpiętości. W związku z powyższym, w połowie kwietnia wystosowano drugie, zmodyfikowane zapytanie ofertowe. Ponieważ wszystkie przedłożone oferty (zarówno w pierwszym, jak i w drugim zapytaniu) przekraczały budżet przeznaczony na opracowanie platformy e-learningowej, Zakład Transfuzjologii wprowadził pewne modyfikacje dotyczące zakresu funkcjonalności platformy, tak aby część obowiązków (np. administracja platformy oraz podstawowe wsparcie dla użytkowników) mogła być przejęta przez pracowników Zakładu.

W dniu 1 czerwca 2018 roku na stronie internetowej Instytutu został ogłoszony przetarg nieograniczony na wyżej wymienioną usługę. W dniu 21 czerwca 2018 roku postępowanie unieważniono na podstawie art. 93 ust. 1 pkt 4 ustawy Pzp. Zawiadomienie o kolejnym postępowaniu przetargowym na wyżej wymienioną usługę Dział Zamówień Publicznych zamieścił na stronie internetowej Instytutu w dniu 26 czerwca 2018 roku.

W dniu 28 sierpnia 2018 roku w Warszawie, w wyniku postępowania o udzielenie zamówienia publicznego prowadzonego $\mathrm{w}$ trybie przetargu nieograniczonego, została zawarta umowa pomiędzy Instytutem Hematologii i Transfuzjologii a firmą INTER IT Sp.z o.o z siedzibą w Gdyni. Przedmiotem wyżej wymienionej umowy było świadczenie przez Wykonawcę na rzecz Instytutu usługi polegającej na przeprowadzeniu wszelkich niezbędnych prac $\mathrm{w}$ zakresie opracowania, prowadzenia i aktualizacji ogólnodostępnej platformy e-learningowej w latach 2018-2020.

\section{Realizacja zadania}

Równolegle $z$ toczącą się procedurą administracyjną dotyczącą postępowania o udzielenie zamówienia publicznego na wyżej wymienioną usługę oraz bezpośrednio po jej zakończeniu w Zakładzie Transfuzjologii wykonano wiele prac dotyczących przygotowania ostatecznych wersji materiałów merytorycznych do umieszczenia na platformie. Prace te obejmowały:

- podział materiałów szkoleniowych na trzy ścieżki edukacyjne (dla lekarzy, pielęgniarek/ /położnych i diagnostów);

- podział każdego wykładu na mniejsze części (ponumerowane);

- przypisanie do każdej części pytań testowych $\mathrm{w}$ formacie umożliwiającym umieszczenie ich na platformie;
- opracowanie techniczne (ujednolicenie) wszystkich materiałów;

- konsultacje wykładowców $z$ wykonawcami dotyczące wprowadzanych zmian;

- przygotowanie wersji skróconych wykładów $\mathrm{w}$ formacie PDF na potrzeby autoryzacji i nanoszenia uwag;

- przekazanie materiałów wykładowcom w celu autoryzacji wykładów po zmianach redaktorskich;

- nanoszenie poprawek wprowadzonych przez wykładowców;

- przygotowanie ostatecznych wersji wykładów do przekazania firmie INTER IT;

- opracowanie wstępnej formy graficznej wykładów przez firmę INTER IT;

- wprowadzanie przez wykładowców poprawek do opracowanych materiałów;

- ustalenie wersji ostatecznej materiałów przed ich nagraniem.

Po podpisaniu umowy $z$ wykonawcą projektu, ze względu na presję czasową, natychmiast przystąpiono do organizowania etapu nagrywania wykładów będących zasadniczym materiałem szkoleniowym do umieszczenia na platformie. Opracowano dokładny harmonogram nagrań. Poszczególne wykłady zostały podzielone na „logiczne" części, a nagranie każdej z takich części powtarzano co najmniej dwa razy. W okresie 19-24 września 2018 roku nagrano ponad 130 części wykładów! Czas samych tylko nagrań to ponad 50 godzin!

Jednocześnie w Zakładzie Transfuzjologii przygotowywano materiały prezentujące poszczególnych wykładowców biorących udział w nagrywaniu materiałów do przedstawienia na platformie. Prezentacje zostały przygotowane według jednego szablonu, który uwzględniał: przedstawienie miejsca pracy, najważniejszych osiągnięć naukowych, dorobku publicystycznego oraz specjalizację. Obok prezentacji dorobku naukowego wykładowcy na platformie zamieszczono również zdjęcia wykładowców.

W dniu 15 listopada 2018 roku przedstawiciele Instytutu i firmy INTER IT przeprowadzili odbiór jakościowy Usługi pn. „Udostępnienie platformy docelowej grupie użytkowników". Zgłoszono zastrzeżenia, które jednakże nie wpływały na samo działanie platformy. Zostały one usunięte przez firmę przed udostępnieniem platformy do użytku.

Efektem tych wspólnych działań było udostępnienie 30 listopada 2018 roku pod adresem: www.krwiolecznictwo-szkolenia.edu.pl platformy e-learning dedykowanej członkom Komitetów 
Transfuzjologicznych, osobom bezpośrednio zaangażowanym w nadzór nad krwiolecznictwem w podmiotach leczniczych oraz wszystkim osobom uczestniczącym w procesach krwiolecznictwa. $\mathrm{Na}$ rycinie 2 przedstawiono ekran główny platformy (ryc. 2A), sposób rejestracji (ryc. 2B) i tworzenia profilu konta użytkownika (ryc. 2C). Strona główna zawiera informacje o dostępnych kursach dla lekarzy, diagnostów i pielęgniarek oraz o następujących dokumentach do pobrania:

- Standard Pracy Komitetu Transfuzjologicznego;

- Wytyczne w zakresie leczenia krwią i jej składnikami oraz produktami krwiopochodnymi w podmiotach leczniczych.

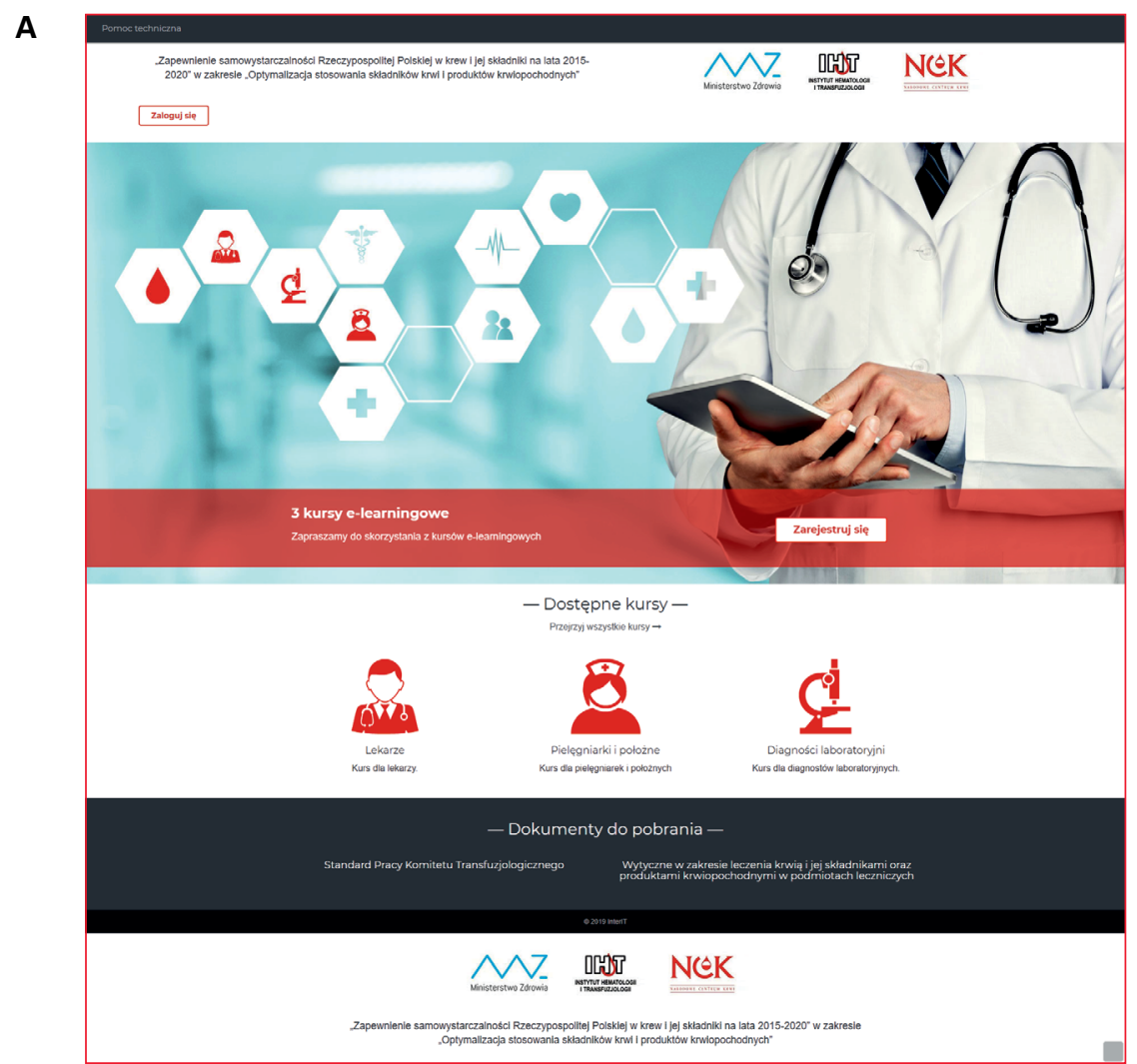

B

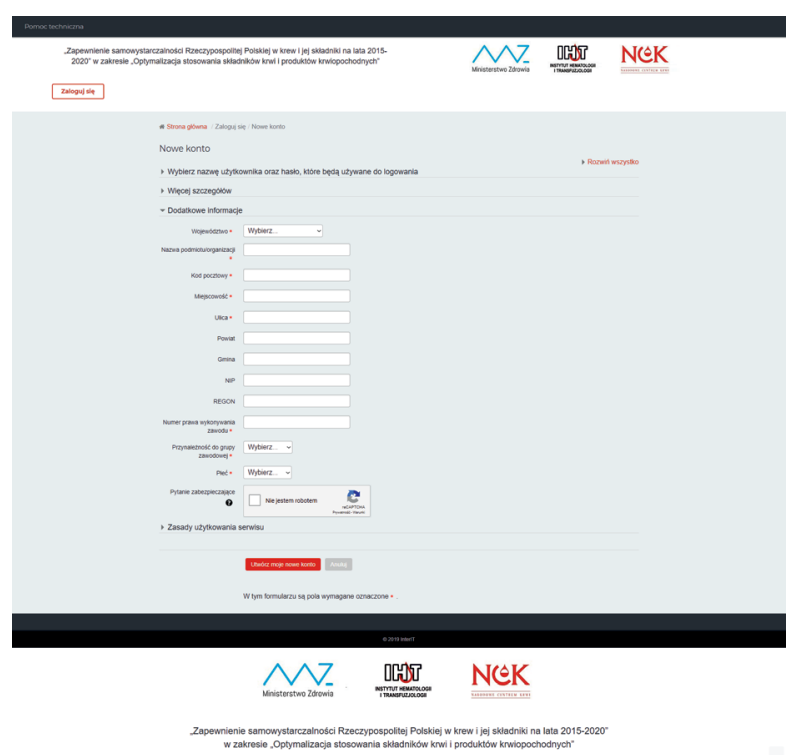

C

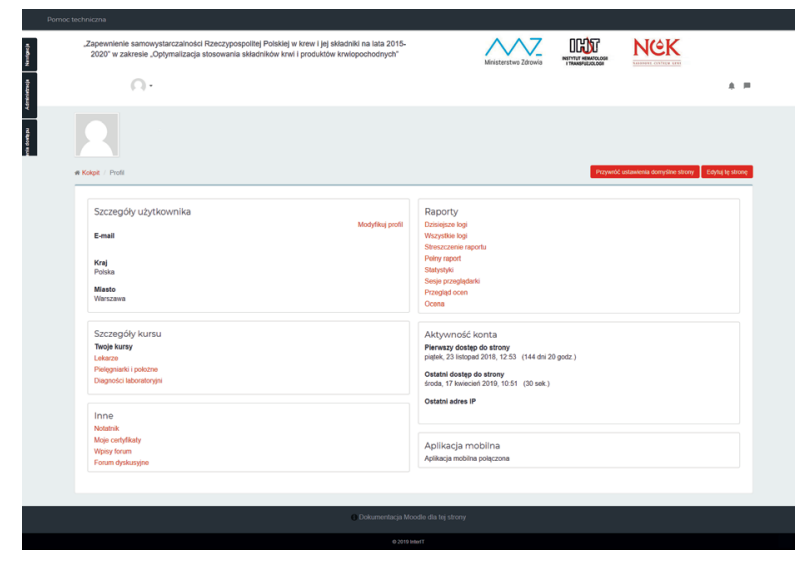

Rycina 2. Print screen ze strony głównej, rejestracji i tworzenia profilu konta użytkownika platformy

Figure 2. Print screen of the main site and log in procedure 


\section{Materialy dodatkowe}

Na platformie umieszczono ponadto materiały w różnych formatach (.ppt, .pdf, .pps) zawierające rozszerzone informacje dotyczące zagadnień przedstawianych w podstawowym module szkoleniowym oraz poświęcone innym zagadnieniom związanym $z$ transfuzjologią. W ten sposób powstała tak zwana Biblioteka, w której użytkownicy platformy znajdą informacje uzupełniające. W Bibliotece umieszczono również linki do:
— „Standardu pracy Komitetu Transfuzjologicznego”;

— „Wytycznych w zakresie leczenia krwią i jej składnikami oraz produktami krwiopochodnymi w podmiotach leczniczych";

- aktualnie obowiązujących aktów prawnych;

- prac (oryginalnych, poglądowych i sprawozdań) publikowanych w czasopiśmie ,Journal of Transfusion Medicine".

Biblioteka ma charakter rozwojowy — kolejne elementy będą dodawane na bieżąco.

\section{Wykłady przygotowane dla lekarzy, pielęgniarek i diagnostów w ramach platformy}

\section{Prezentacja Wykładowców}

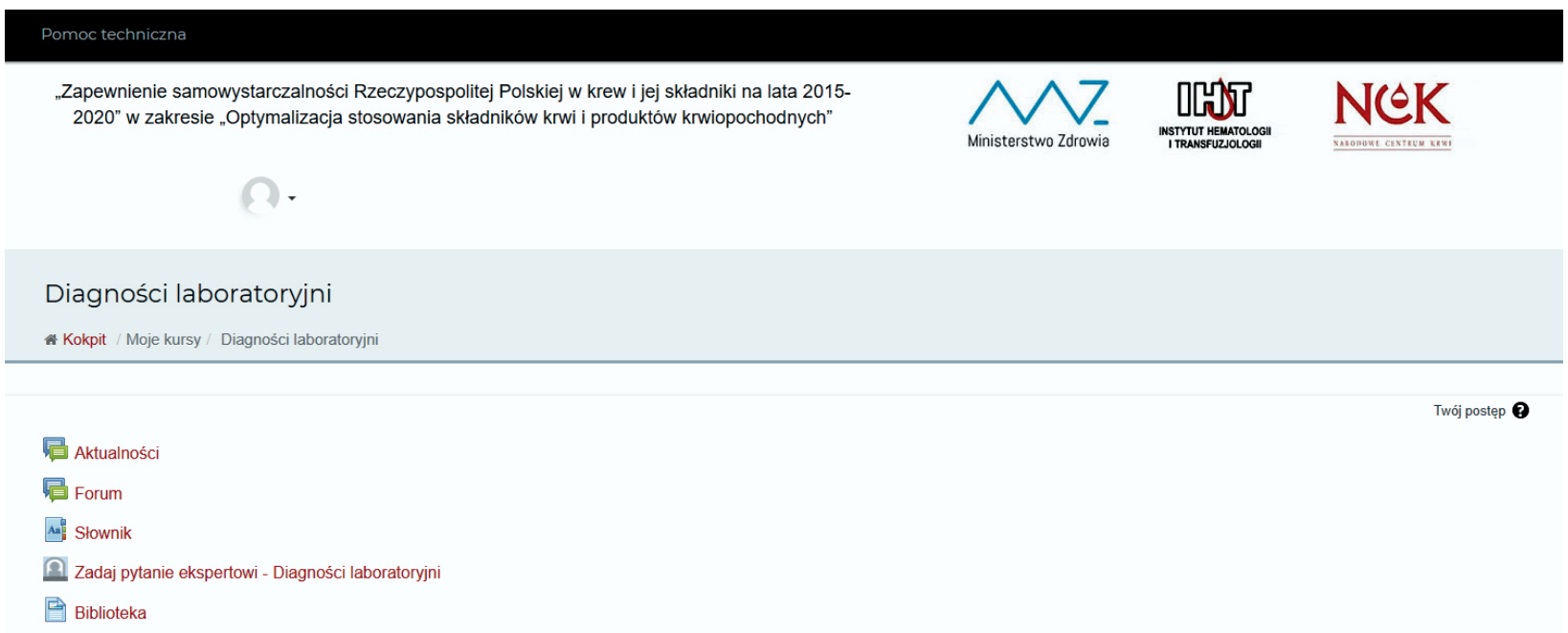

Służba krwi w Polsce ze szczególnym uwzględnieniem aktów prawnych, organizacji leczenia krwią w podmiotach leczniczych oraz znaczenie informatyzacji w krwiolecznictwie - mgr Agata Mikołowska

Mgr Agata Mikołowska - absolwentka Wydziału Nauk Biologicznych Uniwersytetu Zielonogórskiego. Pracownik Pracowni Zapewnienia Jakości w Zakładzie Transfuzjologii Instytutu Hematologii i Transfuzjologii. Głównym obszarem zainteresowan naukowych jest organizacja służby krwi i związane z tym zagadnienia, w tym zapewnienie zaopatrzenia podmiotów leczniczych w bezpieczną krew i jej składniki. Dowiedz się więcej.

I. Służba knwiw Polsce -część 1 
Journal of Transfusion Medicine 2019, tom 12, nr 1

Składniki krwi oraz produkty krwiopochodne - prof. Elżbieta Lachert

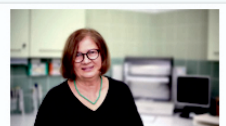

Elżbieta Lachert - Profesor nadzwyczajny doktor habilitowany nauk medycznych, kierownik Pracowni Zapewnienia Jakości w Zakładzie Transfuzjologii, Instytutu Hematologii i Transfuzjologii. Abso/wentka Wydziału Farmacji Akademii Medycznej w Warszawie (obecnie Uniwersytetu Medycznego w Warszawie). Specjalista w dziedzinie laboratoryjnej transfuzjologii medycznej oraz diagnostyki laboratoryjnej. Dowiedz się więcej.

II Składniki krwi - część 1

$$
\text { Pytanie } 1
$$

Pytanie 2

II Składniki krwi - część 2

Dytanie 1

Pytanie 2

II Składniki krwi - część 3

Pytanie 1

Pytanie 2

Metody zwiększania bezpieczeństwa składników krwi - prof. Elżbieta Lachert

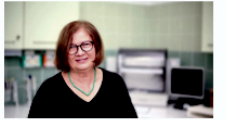

Elżbieta Lachert - Profesor nadzwyczajny doktor habilitowany nauk medycznych, kierownik Pracowni Zapewnienia Jakości w Zakładzie Transfuzjologii,

Instytutu Hematologii i Transfuzjologii. Abso/wentka Wydziału Farmacji Akademii Medycznej w Warszawie (obecnie Uniwersytetu Medycznego w

Warszawie). Specjalista w dziedzinie laboratoryjnej transfuzjologii medycznej oraz diagnostyki laboratoryjnej. Dowiedz się więcej.

П Metody zwiększania bezpieczeństwa - część 1

Pytanie 1

Pytanie 2

IMetody zwiększania bezpieczeństwa - część 2
Pytanie 1
Pytanie 2

\# Metody zwiększania bezpieczeństwa - część 3

Pytanie 1

Pytanie 2

Immunologia transfuzjologiczna: zadania pracowni immunologii transfuzjologicznej i ich znaczenie w bezpiecznym przetaczaniu składników krwi mgr Beata Wojciechowska

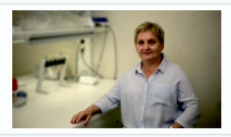

Mgr Beata Wojciechowska - diagnosta laboratoryjny - Kierownik Pracowni Grup Krwi i Prób Zgodności w Zakładzie Immunologii Hematologicznej $i$ Transfuzjologicznej Instytutu Hematologii i Transfuzjologii w Warszawie. Abso/wentka wydziału biologii Uniwersytetu Przyrodniczo-Humanistycznego w Siedlcach. Specjalista w dziedzinie laboratoryjnej transfuzjologii medycznej z wieloletnim dorobkiem naukowym i doświadczeniem dydaktycznym. Dowiedz się więcej.

IImmunologia transfuzjologiczna: zadania - częśść 1

Pytanie 1

Pytanie 2

IImmunologia transfuzjologiczna: zadania - część 2

Pytanie 1

Pytanie 2

\#Immunologia transfuzjologiczna: zadania - część 3

Pytanie 1

Pytanie 2 
Immunologia transfuzjologiczna: dokumentacja pracowni immunologii transfuzjologicznej i banku krwi, system jakości - mgr Beata Wojciechowska

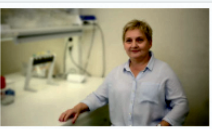

Mgr Beata Wojciechowska - diagnosta laboratoryjny - Kierownik Pracowni Grup Krwi i Prób Zgodności w Zakładzie Immunologii Hematologicznej I Transfuzjologicznej Instytutu Hematologii i Transfuzjologii w Warszawie. Absolwentka wydziału biologii Uniwersytetu Przyrodniczo-Humanistycznego w Siedlcach. Specjalista w dziedzinie laboratoryjnej transfuzjologii medycznej z wieloletnim dorobkiem naukowym i doświadczeniem dydaktycznym. Dowiedz się więcej.

4. Immunologia transfuzjologiczna: dokumentacja - część 1

Pytanie 1

Pytanie 2

II Immunologia transfuzjologiczna: dokumentacja - część 2

Pytanie 1

Pytanie 2

Immunologia transfuzjologiczna: dokumentacja-część 3

Pytanie 1

Pytanie 2

Współpraca oddziału szpitalnego z pracownią immunologii transfuzjologicznej i bankiem krwi - mgr Beata Wojciechowska

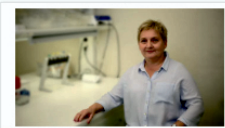

Mgr Beata Wojciechowska - diagnosta laboratoryjny - Kierownik Pracowni Grup Krwi i Prób Zgodności w Zakładzie Immunologii Hematologicznej I

Transfuzjologicznej Instytutu Homatologii i Transfuzjologii w Warszawio. Absolwontka wydzialu biologii Uniworsytetu Przyrodniczo-Humanistycznego n

Siedlcach. Specjalista w dziedzinie laboratoryjnej transfuzjologii medycznej z wieloletnim dorobkiem naukowym i doświadczeniem dydaktycznym.

Dowiedz się wiẹcej.

\#spółpraca oddziału, pracownii i banku - część 1

Pytanie 1

Pytanie 2

\# Współpraca oddziału, pracownii i banku - część 2

Pytanie 1

Pytanie 2

Współpraca oddziału, pracownii i banku - część 3

Pytanie 1

Pytanie 2

Wskazania do stosowania składników krwi i produktów krwiopochodnych - prof. Paweł Łaguna

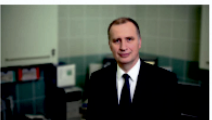

Dr hab.n.med. Paweł Kaguna - abso/went Wydziału Lekarskiego Akademii Medycznej w Warszawie. Specjalista w dziedzinie chorób dziecięcych Specjalista w dziedzinie onkologii i hematologii dziecięcej. Specjalista w dziedzinie transfuzjologii klinicznej. Od 1992r zatrudniony w Warszawskim Uniwersytecie Medycznym. Szczególny obszar zainteresowań to hematologia, zaburzenia krzepnięcia, osoczowe wrodzone skazy krwotoczne jak również transfuzjologia. Dowiedz się więcej.

II. Wskazania do stosowania - część 1

\#skazania do stosowania - część 2

Pytanie 1

Pytanie 2

I. Wskazania do stosowania - część 3

Pytanie 1

Pytanie 2 
Journal of Transfusion Medicine 2019, tom 12, nr 1

Zarządzanie krwią pacjenta, autotransfuzja i zabiegi lecznicze - dr Aleksandra Rosiek

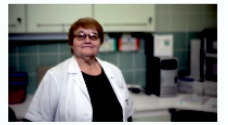

Dr n. med. Aleksandra Rosiek, zatrudniona w Zakładzie Transfuzjologii Instytutu Hematologii i Transfuzjologii w Warszawie. Absolwentka Akademil

Medycznej w Warszawie. Specjalista II stopnia w dziedzinie transfuzjologii klinicznej. Szczególny obszar zainteresowań stanowia kliniczne aspekty

krwiolecznictwa, ze szczególnym uwzględnieniem aferezy leczniczej, jak również czuwanie nad bezpieczeństwem krwi i jej składników. Dowiedz się

więcej.

\# Zarządzanie krwią pacjenta - część 1

Pytanie 1

Pytanie 2

\#Zarządzanie krwią pacjenta - część 2

$$
\text { Pytanie } 1
$$

Pytanie 2

4 Zarządzanie krwią pacjenta - część 3

Pytanie 1

Pytanie 2

Zadania komitetu transfuzjologicznego, lekarza odpowiedzialnego za gospodarkę krwią, pielęgniarki i położnej oraz diagnosty laboratoryjnego w procesie przetaczania - prof. Jolanta Antoniewicz-Papis

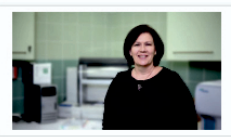

Jolanta Antoniewicz-Papis - profesor nadzwyczajny doktor habilitowany nauk o zdrowiu, zastępca kierownika Zakładu Transfuzjologii w Instytucie Hematologii i Transfuzjologii, kierownik Pracowni Transfuzjologii Laboratoryjnej z bankiem Komórek Krwiotwórczych

Abso/wentka Wydziału Chemii Uniwersytetu Warszawskiego. Specjalista w dziedzinie laboratoryjnej transfuzjologii medycznej oraz w dziedzinie zdrowia

publicznego. Dowiedz się więcej.

I Zadania komitetu transfuzjologicznego - część 1

Pytanie 1

Pytanie 2

II Zadania komitetu transfuzjologicznego - część 2

Pytanie 1

Pytanie 2

II Zadania komitetu transfuzjologicznego - część 3

Pytanie 1

Pytanie 2

Nowoczesne metody rozwiązywania problemów w doborze składników krwi do przetoczenia - dr Bogumiła Michalewska

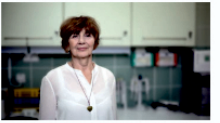

Bogumiła Michalewska - dr nauk farmaceutycznych. Abso/wentka Wydziału Biologii Uniwersytetu im. Marii Skłodowskiej Curie w Lublinie. Emerytowany pracownik Instytutu Hematologii i Transfuzjologii w Warszawie, Zakład Immunologii Hematologicznej i Transfuzjologicznej. Specjalista w dziedzinie

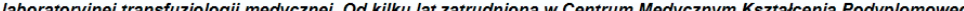

Judniona w Centrum Medycznym Ksztacenia Podyplomowogo w Warszawio na stanowisku

adiunkta naukowo-dydaktycznego. Dowiedz się więcej.

\# Nowoczesne metody doboru składników krwi - część 1

\section{Pytanie 1}

Pytanie 2

Nowoczesne metody doboru składników krwi - część 2

Pytanie 1

Pytanie 2

\#Nowoczesne metody doboru składników krwi - część 3

Pytanie 1

Pytanie 2 
Niepożądane zdarzenia i reakcje w oparciu o przypadki kliniczne - dr Aleksandra Rosiek

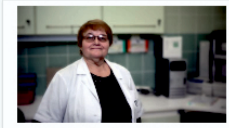

Drn. med. Aleksandra Rosiek, zatrudniona w Zakładzie Transfuzjologii Instytutu Hematologii i Transfuzjologii w Warszawie. Abso/wentka Akademii Medycznej w Warszawie. Specjalista II stopnia w dziedzinie transfuzjologii klinicznej. Szczególny obszar zainteresowan stanowia kliniczne aspekty krwiolecznictwa, ze szczególnym uwzględnieniem aferezy leczniczej, jak również czuwanie nad bezpieczeństwem krwi i jej składników. Dowiedz się więcej.

II Niepożądane zdarzenia i reakcje - cześćć

$$
\begin{aligned}
& \text { Pytanie } 1 \\
& \text { Pytanie 2 }
\end{aligned}
$$

II Niepożądane zdarzenia i reakcje - część 2

$$
\text { Pytanie } 1
$$$$
\text { Pytanie } 2
$$

II. Niepożądane zdarzenia i reakcje - część 3

$$
\begin{aligned}
& \text { Pytanie } 1 \\
& \text { Pytanie } 2
\end{aligned}
$$

Prawidłowe zabezpieczenie szpitala/oddziału/banku krwi w składniki krwi - organizacja banku krwi i jego zadania - prof. Paweł Łaguna

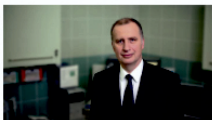

Dr hab.n.med. Paweł Kaguna - abso/went Wydziału Lekarskiego Akademii Medycznej w Warszawie. Specjalista w dziedzinie chorób dziecięcych. Specjalista w dziedzinie onkologii i hematologii dzjeciecej. Specjalista w dziedzinio transfuzjologii klinicznej. Od 1992r zatrudniony w Warszawskim Uniwersytecie Medycznym. Szczególny obszar zainteresowań to hematologia, zaburzenia krzepnięcia, osoczowe wrodzone skazy krwotoczne jak równie Uniwersytecie Medycznym. Szczeg
transfuzjologia. Dowiedz się więcej.

I Prawidłowe zabezpieczenie w składniki krwi - część 1

$$
\begin{aligned}
& \text { Pytanie } 1 \\
& \text { Pytanie } 2
\end{aligned}
$$

\# Prawidłowe zabezpieczenie w składniki krwi - częeść 2

Pytanie 1

Pytanie 2

Czynniki zakaźne przenoszone drogą krwi - mgr Aneta Kopacz, prof. Piotr Grabarczyk, mgr Aleksandra Kalińska, mgr Ewa Sulkowska, mgr Zuzanna Dziąg

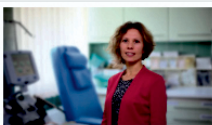

Mgr Aneta Kopacz, kierownik Pracowni Kontroli Jakości i Analiz w Zakładzie Wirusologii Instytutu Hematologii i Transfuzjologii w Warszawie. Abso/wentka studiow Biotechnologia na Uniwersytecie Marii Skłodowskiej-Curie w Lublinie i podyplomowych studiow Analityka Medyczna na Uniwersytecie Warszawskim. Specjalista w dziedzinie: wirusologii, w szczególności czynników zakaźnych przenoszonych drogą transfuzji krwi i jej składników. Dowiedz się więcej.

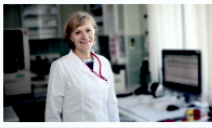

Mgr Ewa Sulkowska: Kierownik Pracowni Badań Weryfikacyjnych w Zakładzie Wirusologii. Instytut Hematologii i Transfuzjologii w Warszawie. Abso/wentka wydziału biologii Uniwersytetu Przyrodniczo-Humanistycznego w Siedlcach. Specjalista w dziedzinie laboratoryjnej transfuzjolog medycznej z ogromnym dorobkiem naukowym i wieloletnim doświadczeniem w zakresie przygotowywania i prowadzenia prowadzenia wykładów dla lekarzy. Dowiedz się więcej.

II Czynniki zakaźne - czẹść 1

Pytanie 1

Pytanie 2 - nowe

ㅁ. Czynniki zakaźne-część 2

Pytanie 1

Pytanie 2

II Czynniki zakaźne- cześć 3

Pytanie 1

Pytanie 2

II Czynniki zakaźne-część 4

Pytanie 1

Pytanie 2

II Czynniki zakażne-część 5

Pytanie 1

Pytanie 2 


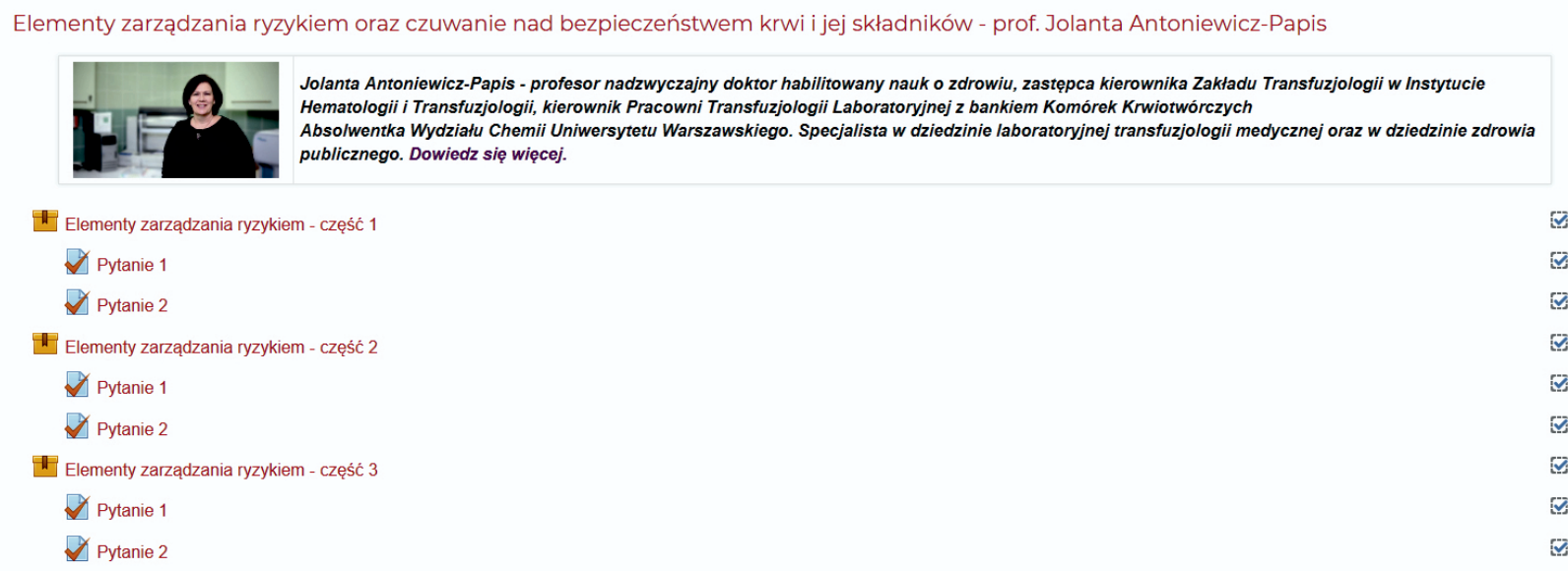

Podsumowanie
Test końcowy

Poniżej przedstawiono widok ekranu, który ukazuje się użytkownikowi zalogowanemu na platformie po kliknięciu „Wykład” (ryc. 3). Jest to przykład ze ścieżki dla diagnostów.

Na przykładzie ścieżki dla diagnostów przedstawiamy serię „print screens”, które ilustrują drogę, jaką każdy użytkownik platformy musi przebyć, aby uzyskać Certyfikat ukończenia kursu (ryc. 4).

Przykładowy ekran ilustrujący wynik zaliczonego testu końcowego (ryc. 5A, B).

Istotne jest to, $\dot{z}$ e dopiero po wysłuchaniu wszystkich wykładów i zaliczeniu testu końcowego każdy z uczestników może pobrać Certyfikat (ryc. 6).

Zgodnie $z$ zapisami Umowy do zadań Instytutu od chwili uruchomienia platformy należy:

- nieprzerwane prowadzenie i administrowanie platformy (tj. zarządzanie dostępem do platformy, zarządzanie treścia);

- udzielanie odpowiedzi na pytania kierowane do eksperta;

- propagowanie platformy wśród podmiotów leczniczych i personelu medycznego;

- promowanie platformy na portalu społecznościowym Facebook.
Inne działania związane $\mathrm{z}$ realizacją zadania „Optymalizacja stosowania składników krwi i produktów krwiopochodnych" w 2018 roku

Działania przygotowawcze do nowelizacji/ aktualizacji Standardu Pracy Komitetów Transfuzjologicznych przewidzianej w 2019 roku

Jak wspomniano we wcześniejszej publikacji, w 2017 roku opublikowano w formie elektronicznej w dwóch formatach (PDF i e-book) „Standard Pracy Komitetu Transfuzjologicznego" opracowany przy udziale ekspertów $z$ Instytutu oraz ekspertów zewnętrznych. Dokument udostępniono na stronie internetowej Instytutu w zakładce Działalność Instytutu/Działalność Naukowa/Działalność Wydawnicza. Dołożono wszelkich starań, aby materiał zawarty w dokumencie był pomocny w codziennej pracy komitetów transfuzjologicznych, jednocześnie jednak autorzy uznali, że opublikowany materiał warto wzbogacić o doświadczenia i wiedzę praktyczną pochodzące $z$ codziennej działalności komitetów transfuzjologicznych na terenie całego kraju. W związku z powyższym w 2018 roku Instytut wielokrotnie zachęcał do zgłaszania wszelkich uwag i opinii na temat opublikowanego dokumentu (na adres poczty elektronicznej: standard-KT@ihit. waw.pl $z$ dopiskiem w tytule „Standard KT”), licząc 


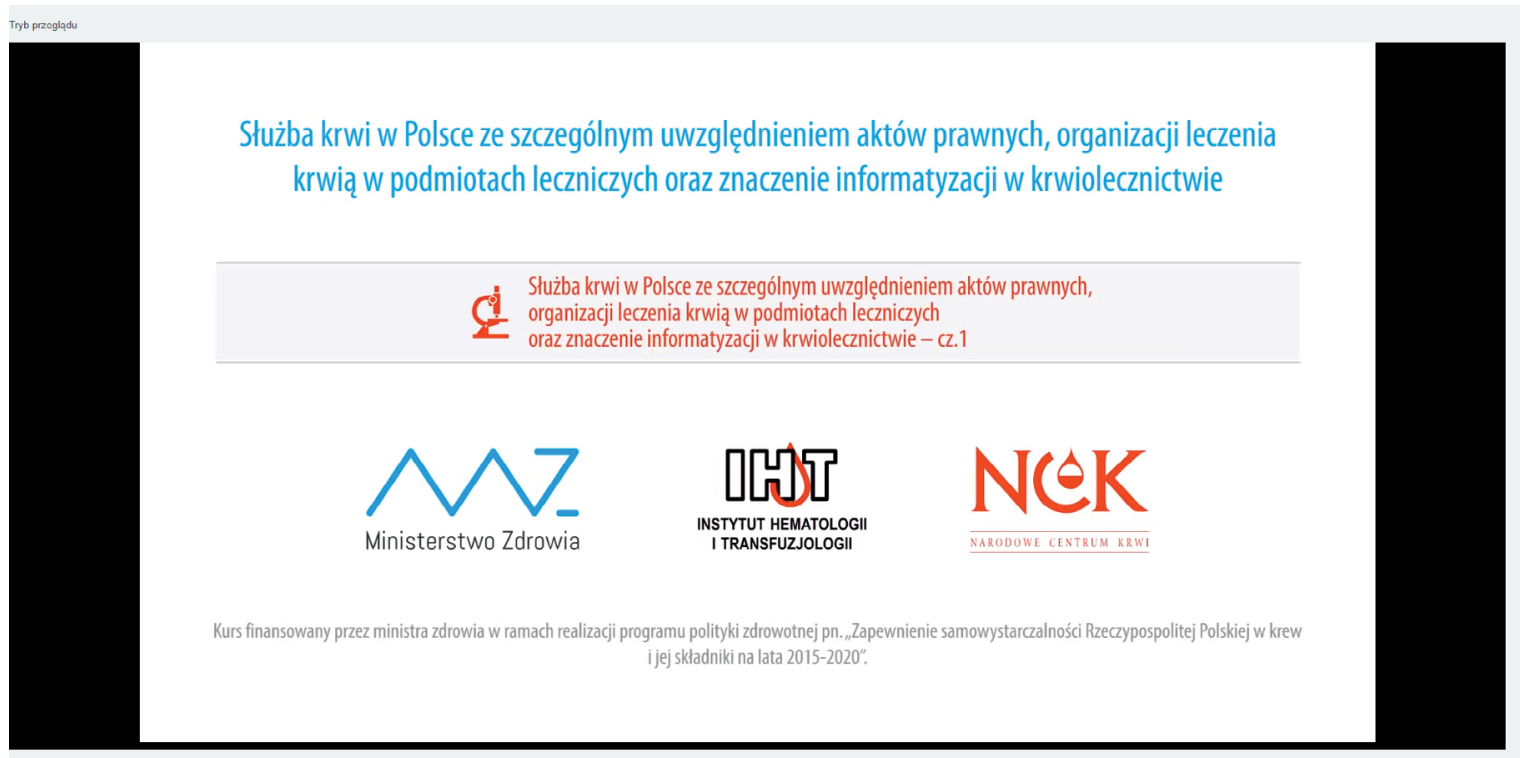

Rycina 3. Widok ekranu po kliknięciu "Wykład"

Figure 3. Screen after clicking on "Lecture"

A

\section{Pomoc tecniczna Moje kursy ^ Mój kokpit}
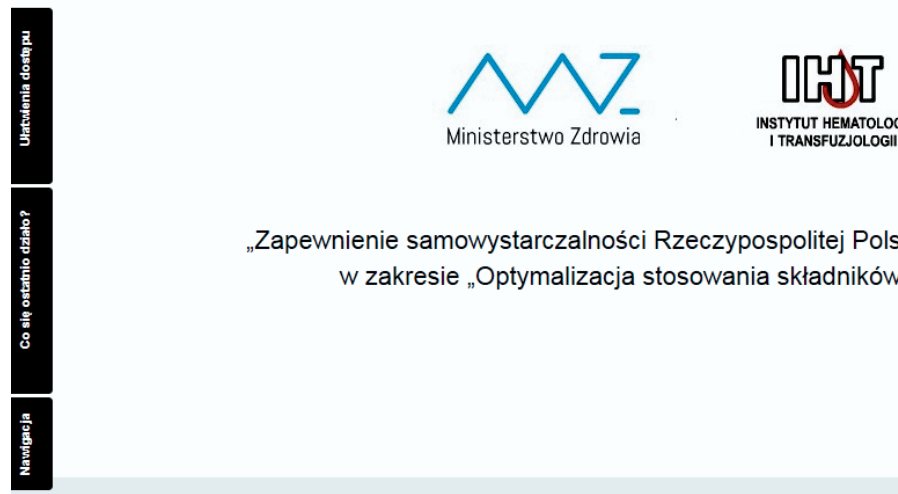

INSTYTUT HEMATOLOGI
I TRANSFUZJOLOGII

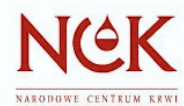

„Zapewnienie samowystarczalności Rzeczypospolitej Polskiej w krew i jej składniki na lata 2015-2020” w zakresie „Optymalizacja stosowania składników krwi i produktów krwiopochodnych”

Diagności laboratoryjni

hokpit / Moje kursy / Diagności laboratoryjni

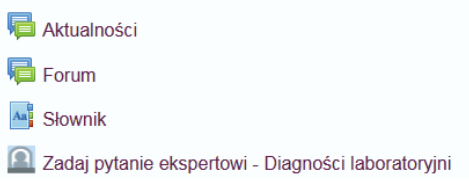

Rycina 4. Ilustracja "drogi” użytkownika platformy od rozpoczęcia szkolenia do uzyskania Certyfikatu

Figure 4. Lectures each a user has to pass before receiving a Certificate 
B

\section{Pomoc tecniczna Moje kursy $\vee$ Mój kokpit $\vee$}

Służba krwi w Polsce ze szczególnym uwzględnieniem aktów prawnych, organizacji leczenia krwią w podmiotach leczniczych oraz znaczenie informatyzacji w krwiolecznictwie - mgr Agata Mikołowska

Służba krwi w Polsce - część 1

Pytanie 1

Pytanie 2

Służba krwi w Polsce-część 2

Pytanie 1

Pytanie 2

Służba krwi w Polsce - część 3

Pytanie 1

Pytanie 2

(7)

C

Pomoc tecniczna Moje kursy $\vee$ Mój kokpit $\vee$

Składniki krwi oraz produkty krwiopochodne - prof. Elżbieta Lachert

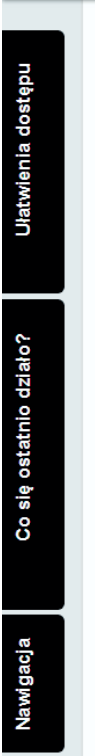

Składniki krwi - część 1

S

Pytanie 1

ב

Pytanie 2

ב

I Składniki krwi - część 2

E)

Pytanie 1

Q

Pytanie 2

ב

I Składniki krwi-część 3

Q

Pytanie 1

ב

Pytanie 2

s

7

Metody zwiększania bezpieczeństwa składników krwi - prof. Elżbieta

Rycina 4 (cd.). Ilustracja „drogi” użytkownika platformy od rozpoczęcia szkolenia do uzyskania Certyfikatu

Figure 4 (cont.). Lectures each a user has to pass before receiving a Certificate 
D

\section{Pomoc tecniczna Moje kursy $\vee$ Mój kokpit $\vee$}

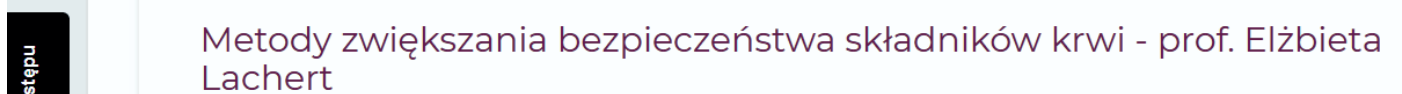
Lachert

Metody zwiększania bezpieczeństwa - część 1

Pytanie 2

Metody zwiększania bezpieczeństwa - część 2

Pytanie 1

Pytanie 2

$\square$ Metody zwiększania bezpieczeństwa - część 3

\section{Pomoc tecniczna Mojekursy $\vee$ Mój kokpit $\vee$}

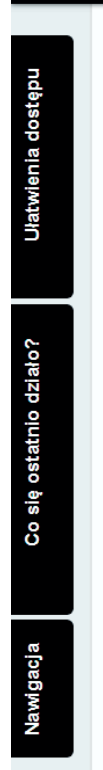

Immunologia transfuzjologiczna: zadania pracowni immunologii transfuzjologicznej i ich znaczenie w bezpiecznym przetaczaniu składników krwi - mgr Beata Wojciechowska

II Immunologia transfuzjologiczna: zadania - część 1

$$
\text { Pytanie } 1
$$

Pytanie 2

Immunologia transfuzjologiczna: zadania - część 2

\section{Pytanie 1}

Pytanie 2

Immunologia transfuzjologiczna: zadania - część 3

\section{Pytanie 1}

Pytanie 2

Rycina 4 (cd.). Ilustracja „drogi” użytkownika platformy od rozpoczęcia szkolenia do uzyskania Certyfikatu

Figure 4 (cont.). Lectures each a user has to pass before receiving a Certificate 


\section{$\mathbf{F}$}

\section{Pomoc tecniczna $\quad$ Moje kursy $\vee$ Mój kokpit $\vee$}

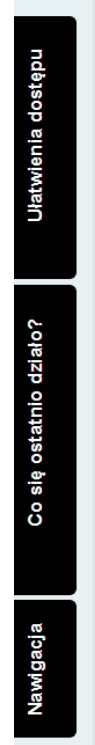

Immunologia transfuzjologiczna: dokumentacja pracowni immunologii transfuzjologicznej i banku krwi, system jakości - mgr Beata Wojciechowska

Immunologia transfuzjologiczna: dokumentacja - część 1

[x

Pytanie 1

[X]

Pytanie 2

[X]

Immunologia transfuzjologiczna: dokumentacja - część 2

(צ)

Pytanie 1

צ.

Pytanie 2

[X]

Immunologia transfuzjologiczna: dokumentacja - część 3

(צ)

Pytanie 1

Q

Pytanie 2

ş

\section{G}

Współpraca oddziału szpitalnego z pracownią immunologii transfuzjologicznej i bankiem krwi - mgr Beata Wojciechowska

Współpraca oddziału, pracownii i banku - część 1

Współpraca oddziału, pracownii i banku - część 2

Współpraca oddziału, pracownii i banku - część 3

Rycina 4 (cd.). Ilustracja „drogi” użytkownika platformy od rozpoczęcia szkolenia do uzyskania Certyfikatu

Figure 4 (cont.). Lectures each a user has to pass before receiving a Certificate 
H

\section{Pomoc tecniczna Moje kursy v Mój kokpit v}

Wskazania do stosowania składników krwi i produktów krwiopochodnych - prof. Paweł Łaguna

IV

Wskazania do stosowania - część 1

Q

Pytanie 1

Q

Pytanie 2

Q

Wskazania do stosowania - część 2

Q

Pytanie 1

Q

Pytanie 2

Q

감

Wskazania do stosowania - część 3

(צ)

Pytanie 1

(צ)

Pytanie 2

בצ

(3)

I

\section{Pomoc tecniczna}

붑 Moje kursy v

2. Mój kokpit $\vee$

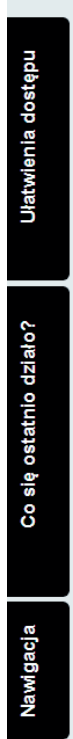

Zarządzanie krwią pacjenta, autotransfuzja i zabiegi lecznicze - dr Aleksandra Rosiek

Zarządzanie krwią pacjenta - część 1

Pytanie 1

Pytanie 2

$\square$ Zarządzanie krwią pacjenta - część 2

Pytanie 1

Pytanie 2

Zarządzanie krwią pacjenta - część 3

Pytanie 1

Pytanie 2

미

Rycina 4 (cd.). Ilustracja „drogi” użytkownika platformy od rozpoczęcia szkolenia do uzyskania Certyfikatu

Figure 4 (cont.). Lectures each a user has to pass before receiving a Certificate 
$\mathbf{J}$ Pomoc tecniczna

분 Moje kursy $\vee$

Mój kokpit v

Zadania komitetu transfuzjologicznego, lekarza odpowiedzialnego za gospodarkę krwią, pielęgniarki i położnej oraz diagnosty laboratoryjnego w procesie przetaczania - prof. Jolanta Antoniewicz-Papis

Zadania komitetu transfuzjologicznego - część 1

(2)

Pytanie 1

(2)

Pytanie 2

בצ

Zadania komitetu transfuzjologicznego - część 2

ב

Pytanie 1

בצ'

Pytanie 2

(2)

Zadania komitetu transfuzjologicznego - część 3

(3)

Pytanie 1

בצ

Pytanie 2

ב

K

\section{Pomoc tecniczna Moje kursy v Mój kokpit v}

Nowoczesne metody rozwiązywania problemów w doborze składników krwi do przetoczenia - dr Bogumiła Michalewska

Nowoczesne metody doboru składników krwi - część 1

ב

Pytanie 1

בצ

Pytanie 2

(2)

Nowoczesne metody doboru składników krwi - część 2

(4)

Pytanie 1

בצ

Pytanie 2

(2)

$\square$ Nowoczesne metody doboru składników krwi - część 3

ב.

Pytanie 1

ב.

Pytanie 2

בצ'

미

Rycina 4 (cd.). Ilustracja "drogi” użytkownika platformy od rozpoczęcia szkolenia do uzyskania Certyfikatu

Figure 4 (cont.). Lectures each a user has to pass before receiving a Certificate 
$\mathbf{L}$

\section{Pomoctecniczna Maje kursy v Mój kokpit v}

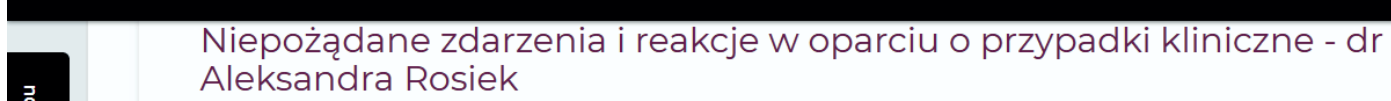
Aleksandra Rosiek

Niepożądane zdarzenia i reakcje - część 1

Pytanie 1

Pytanie 2

$\square$ Niepożądane zdarzenia i reakcje - część 2

Pytanie 2

Niepożądane zdarzenia i reakcje - część 3

Pytanie 2

$七$

Prawidłowe zabezpieczenie szpitala/oddziału/banku krwi w składniki krwi - organizacja banku krwi i jego zadania prof. Paweł Łaguna

ㄱ. Prawidłowe zabezpieczenie w składniki krwi - część 1

Prawidłowe zabezpieczenie w składniki krwi - część 2

Rycina 4 (cd.). Ilustracja "drogi” użytkownika platformy od rozpoczęcia szkolenia do uzyskania Certyfikatu

Figure 4 (cont.). Lectures each a user has to pass before receiving a Certificate 
$\mathbf{M}$

\section{Pomoc tecniczna 쿨 Moje kursy $\vee$ Mójkokpit}

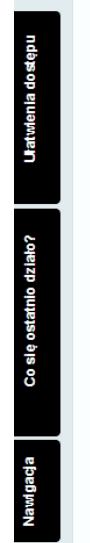

Czynniki zakaźne przenoszone drogą krwi - mgr Aneta Kopacz, prof. Piotr Grabarczyk, mgr Aleksandra Kalińska, mgr Ewa Sulkowska, mgr Zuzanna Dziąg

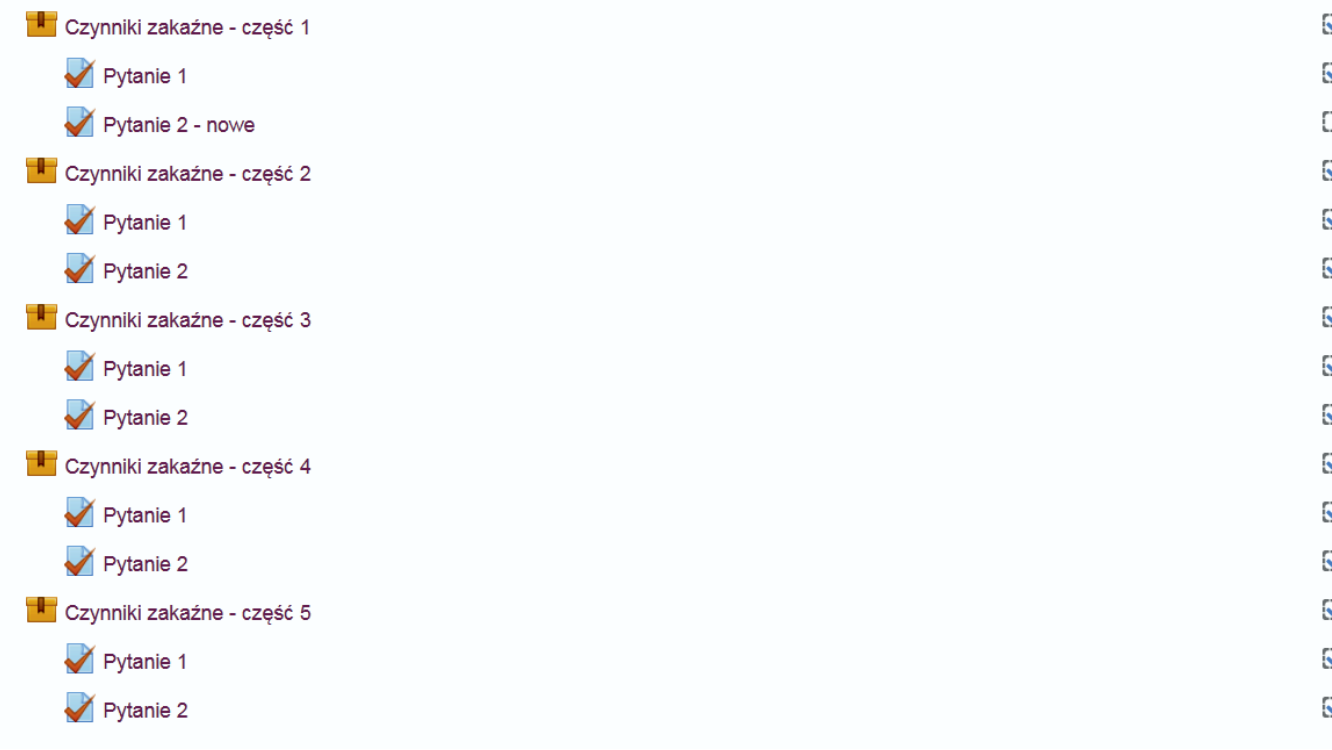

N

\section{Pomoc tecniczna

Elementy zarządzania ryzykiem oraz czuwanie nad bezpieczeństwem krwi i jej składników - prof. Jolanta Antoniewicz-Papis

Elementy zarządzania ryzykiem - część 1

Pytanie 1

Pytanie 2

Elementy zarządzania ryzykiem - część 2

Pytanie 1

Pytanie 2

Elementy zarządzania ryzykiem - część 3

Pytanie 1

Rycina 4 (cd.). Ilustracja „drogi” użytkownika platformy od rozpoczęcia szkolenia do uzyskania Certyfikatu

Figure 4 (cont.). Lectures each a user has to pass before receiving a Certificate 
A

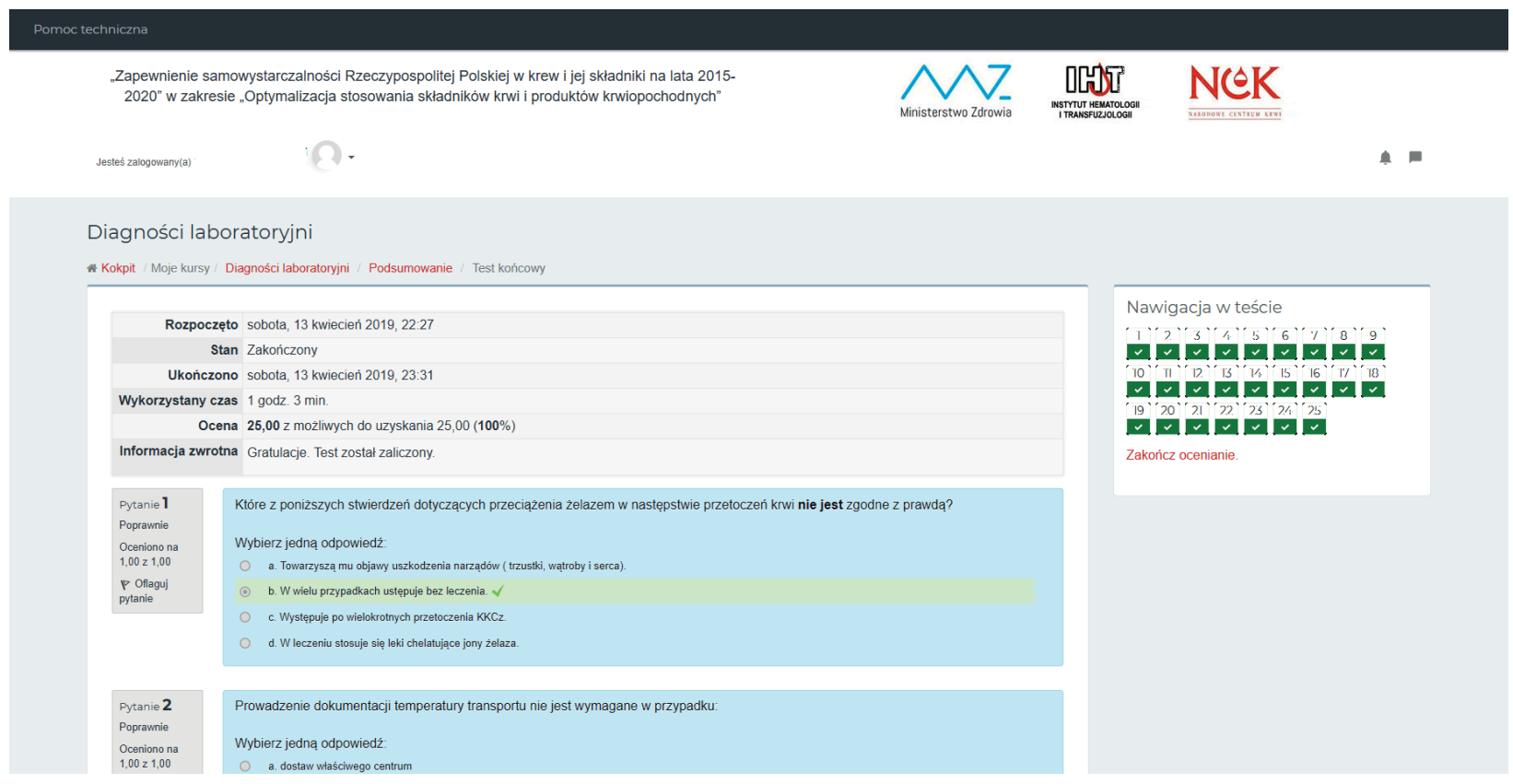

B

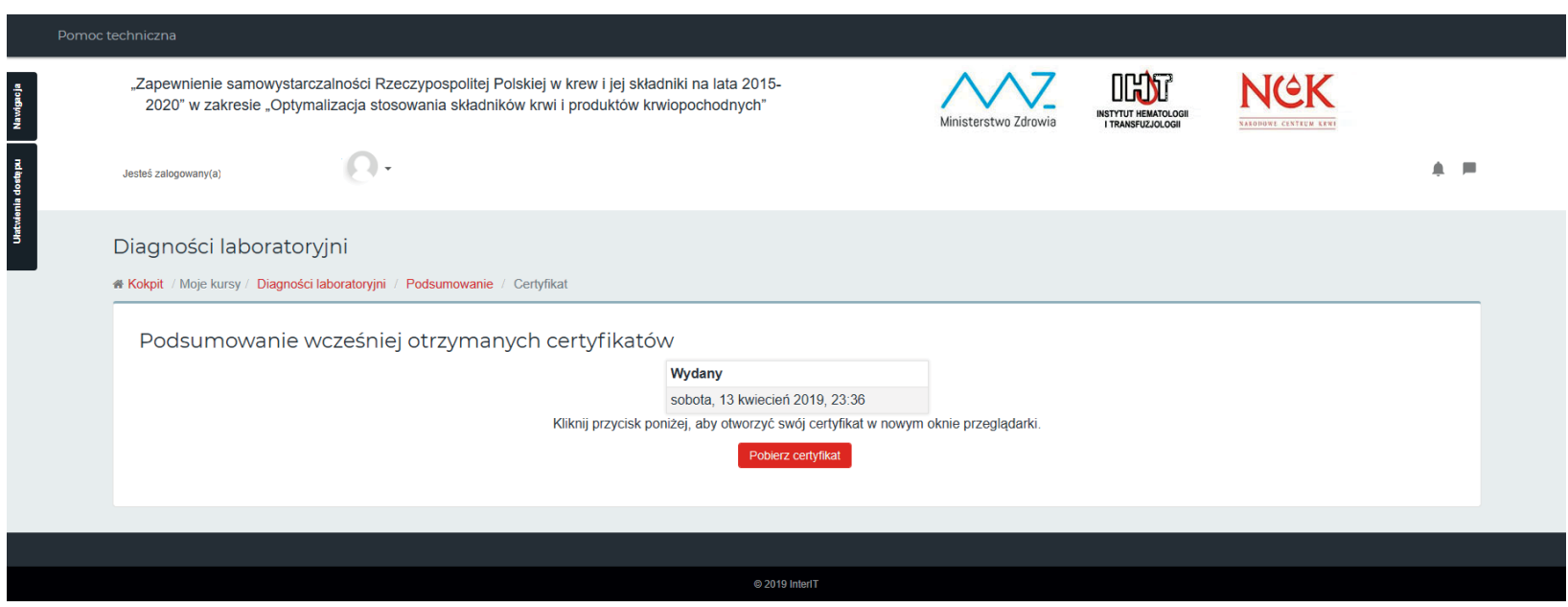

Rycina 5. Przykładowy ekran ilustrujący wynik zaliczonego tekstu końcowego

Figure 5. Print screen for the outcome of the final test

na to, że przekazane doświadczenia własne w postaci uwag i opinii będą stanowić cenny wkład w przygotowanie nowelizacji „Standard Pracy Komitetu Transfuzjologicznego" zaplanowanej na 2019 rok. W trakcie 2018 roku prowadzono korespondencję i rejestrowano wszystkie zgłaszane opinie i uwagi; przygotowano w ten sposób wkład do wykorzystania w pracach nad „Standardem Pracy Komitetu Transfuzjologicznego” w 2019 roku.

Podsumowanie dwóch lat działalności Zakładu Transfuzjologii Instytutu Hematologii i Transfuzjologii na rzecz realizowania zadania
„Optymalizacja stosowania składników krwi i produktów krwiopochodnych" w ramach programu polityki zdrowotnej pn. „Zapewnienie samowystarczalności Rzeczypospolitej Polskiej w krew i jej składniki na lata 2015-2020".

Od momentu podpisania Umowy nr NCK-F/ /UM/PPZ/69/2017 w dniu 18 sierpnia 2017 roku Zakład Transfuzjologii wykonał następujące działania na rzecz realizacji wyżej wymienionego programu:

1. W ramach szkoleń stacjonarnych przeszkolono w sumie 370 osób $z$ terenu całej Polski, w tym: - 112 lekarzy (32 i 80 odpowiednio w $2017 \mathrm{r}$. i 2018 r.); 


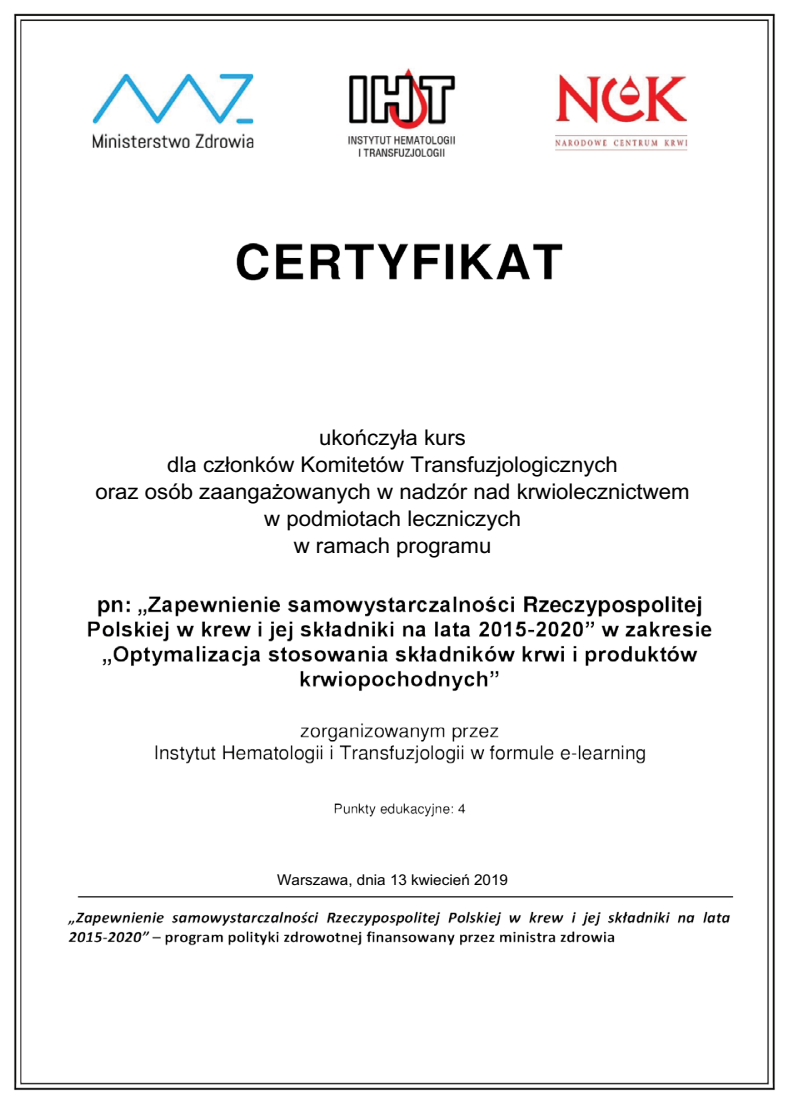

Rycina 6. Certyfikat dla diagnosty uzyskany po ukończeniu kursu na platformie

Figure 6. Certificate-template obtained after completing the course on the e-learning platform. An example from the laboratory diagnostitians path

- 131 pielęgniarek/położnych (45 i 86 odpowiednio w 2017 r. i 2018 r.);

- 127 diagnostów (42 i 85 odpowiednio w 2017 r. i 2018 r.).

kursu.

Wydano w sumie $\mathbf{3 7 0}$ Certyfikatów ukończenia

2. Opracowano „Standard pracy Komitetu Transfuzjologicznego", który został opublikowany w dwóch formatach (PDF i e-book).

3. Uruchomiono ogólnodostępną platformę e-learningową dedykowaną członkom Komitetów Transfuzjologicznych, osobom bezpośrednio zaangażowanym w nadzór nad krwiolecznictwem w podmiotach leczniczych oraz wszystkim osobom uczestniczącym $\mathrm{w}$ procesach krwiolecznictwa.
Plany związane $z$ dalszą realizacją zadania „Optymalizacja stosowania składników krwi i produktów krwiopochodnych".

Zgodnie $z$ postanowieniami Umowy nr NCK-F/UM/PPZ/69/2017 z dnia 18 sierpnia 2017 roku w 2019 roku zaplanowano:

1. Czynności przygotowawcze w celu opracowania aktualizacji „Standardu pracy Komitetu Transfuzjologicznego", w tym:

- uzyskanie od wszystkich centrów krwiodawstwa i krwiolecznictwa (CKiK) materiałów do analizy w postaci protokołów $\mathrm{z}$ kontroli w podległych CKiK podmiotach leczniczych (2018 r.) oraz rocznych sprawozdań $z$ działalności komitetów transfuzjologicznych (2018 r.);

- zakupienie literatury fachowej jako źródła aktualnej wiedzy światowej z zakresu transfuzjologii.

2. Przeprowadzenie kolejnych stacjonarnych szkoleń dla osób zaangażowanych w nadzór nad krwiolecznictwem w podmiotach leczniczych oraz członków Komitetów Transfuzjologicznych.

3. Działanie w zakresie platformy e-learningowej obejmujące:

— utrzymanie platformy i monitorowanie jej działania;

- promowanie platformy na portalach spolecznościowych, przekazywanie aktualnych danych o platformie w kampaniach mailowych;

- wsparcie techniczne i merytoryczne dla użytkowników platformy;

- udzielanie przez ekspertów odpowiedzi na pytania zadawane przez użytkowników (Forum „Zadaj pytanie ekspertowi”);

- współpraca na bieżąco z Wykonawcą platformy;

- raportowanie.

W 2020 roku zaplanowano:

1. Przeprowadzenie kolejnych stacjonarnych szkoleń dla osób zaangażowanych w nadzór nad krwiolecznictwem w podmiotach leczniczych oraz członków Komitetów Transfuzjologicznych.

2. Działanie w zakresie platformy e-learningowej obejmujące:

- aktualizację ścieżek szkoleniowych i ich opublikowanie na platformie;

- utrzymanie platformy i monitorowanie jej działania na bieżąco.

3. Opublikowanie „Standardu pracy Komitetu Transfuzjologicznego" w wersji książkowej/ /papierowej. 